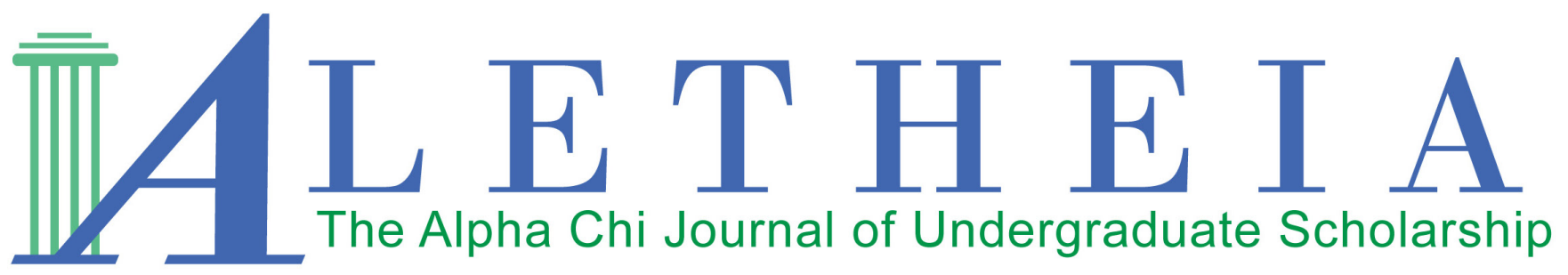

Volume 2 | Issue 2 | 2017

\title{
Voiceless No More: An Examination of African American Political Mistrust, Efficacy, and Political Participation
}

\author{
Megan McKinley \\ Oklahoma Christian University \\ Oklahoma Epsilon Chapter
}

Vol. 2(2), 2017

Article Title: Voiceless No More: An Examination of African American Political Mistrust, Efficacy, and Political Participation

DOI: $10.21081 / \mathrm{AX} 0095$

ISSN: $2381-800 \mathrm{X}$

Key Words: African American, political participation, political efficacy, descriptive representation This work is licensed under a Creative Commons Attribution 4.0 International License.

Author contact information is available from the Editor at editor@alphachihonor.org.

\section{Aletheia-The Alpha Chi Journal of Undergraduate Scholarship}

- This publication is an online, peer-reviewed, interdisciplinary undergraduate journal, whose mission is to promote high quality research and scholarship among undergraduates by showcasing exemplary work.

- Submissions can be in any basic or applied field of study, including the physical and life sciences, the social sciences, the humanities, education, engineering, and the arts.

- Publication in Aletheia will recognize students who excel academically and foster mentor/mentee relationships between faculty and students.

- In keeping with the strong tradition of student involvement in all levels of Alpha Chi, the journal will also provide a forum for students to become actively involved in the writing, peer review, and publication process.

- More information and instructions for authors is available under the publications tab at www.AlphaChiHonor.org. Questions to the editor may be directed to editor@alphachihonor.org.

\footnotetext{
Alpha Chi is a national college honor society that admits students from all academic disciplines, with membership limited to the top 10 percent of an institution's juniors, seniors, and graduate students. Invitation to membership comes only through an institutional chapter. A college seeking a chapter must grant baccalaureate degrees and be regionally accredited. Some 300 chapters, located in almost every state, induct approximately 12,000 members annually. Alpha Chi members have been "making scholarship effective for good" since 1922.
} 
Volume 2 | Issue 2 | Fall 2017

Article Title: Voiceless No More: An Examination of African American Political Mistrust, Efficacy, and Political

Participation DOI: 10.21081/AX0095

ISSN: $2381-800 \mathrm{X}$

This work is licensed under a Creative Commons Attribution 4.0 International License.

\title{
Voiceless No More: An Examination of African American Political Mistrust, Efficacy, and Political Participation
}

\author{
Megan McKinley \\ Oklahoma Christian University \\ Oklahoma Epsilon Chapter
}

\begin{abstract}
In a world of political strife, polarization, and voter alienation, African American voter participation in the political process faces unique challenges. Due to a history of discrimination and a modern reality of low descriptive representation, African American political participation remains low. However, several different factors contribute to an increase in rates of participation.
\end{abstract}

Key words: African American, political participation, political efficacy, descriptive representation

To many African Americans, the last century of US history is the story of a continuous battle for basic human rights and political privileges. Segregation, violence, and blatant discrimination have characterized many aspects of the black experience. As a result of years of discrimination, African Americans perceive themselves to be less adequately represented than other ethnic groups and have generally higher levels of mistrust in the political system. For a majority of African Americans, the government seems to be a distant entity deaf to the voices of black constituents. Many doubt that political leaders care to further the interests of blacks as a group. To further understand both the black experience and protect the fairness of the democratic process, existing research on political cynicism must be examined. Feelings of racial group consciousness, historical discrimination, and lack of descriptive representation lead to political mistrust among African Americans along with higher levels of political efficacy. This ultimately contributes to higher levels of political participation.

\section{Racial Group Consciousness}

This article will show that academia has produced a wide range of literature on the subject of African American political mistrust and political participation. However, before examining political mistrust fully, it is helpful to discuss the idea of racial group consciousness and its effect on political participation. Racial group consciousness involves an individual's group identification, preference for interactions with members of the same race, comparison of the group's status and resources to other groups, and systemic blame (Austin 2012: 631). A heightened awareness of membership in a particular group lead to different levels of participation and ultimately political mistrust. Austin, Middleton, and Yon conducted a study involving individuals of African descent in California and discovered that racial group consciousness had more of an impact on African Americans than other black ethnics. Overall, African Americans with higher levels of group consciousness also have 
higher levels of political participation. This phenomenon brings up the question of how black consciousness impacts political mistrust.

Taylor (2010) studied the research of numerous different scholars who studied racial group consciousness and its effect on African Americans. This analysis begins with a quotation from Richard D. Shingles: "The primary reason black consciousness has such a dramatic effect on political participation is that it contributes to the combination of a sense of political efficacy and political mistrust which in turn induces political involvement" (Shingles 1981, 77). Scholars, such as Agger, Goldstein, Pearl, Southwell, and Jackson, all agree with this conclusion and present evidence to support it. Their findings will be discussed throughout the remainder of this article. Referencing her own research, Taylor argues that the majority of African Americans are politically cynical. These feelings of impotency, inefficacy, and helplessness usually lead to apathy about the system one cannot control, while cynicism has an entirely different effect. Taylor (2010) also argues that, "Where there are higher cynical attitudes among Black voters, there is also higher African American voter turnout'" (Taylor, 2010, 3). In other words, African Americans with a strong sense of racial group consciousness feel dissatisfied with the system and wish to change it any way they can.

Avery (2009) observed that African Americans with heightened "racial group consciousness," a strong sense of identification with a particular racial group, are typically more aware of unequal treatment of members of their race. Perhaps due to this awareness, over a quarter of African Americans support the idea of an independent black political party, a theory that supports Avery's argument of mistrust influencing actions. Avery argued that African American mistrust of the political system leads to the desire for substantial political change, a desire revealed in support of an independent black political party and a high likelihood of involvement in political activism. According to the author, this is mistrust of the system itself rather than merely current political incumbents, African Americans are more likely to be involved in political activism. This distinction is significant: political mistrust can take many forms, but mistrust of the political system is extremely different than mistrust of politicians. When a large group of voters believe that regardless of what they say or support, the system will prevent their voices from being heard, there is clearly a problem in the political process.
Avery's point is interesting, but the findings of other scholars help to complete the picture. Southwell, et al (911) and others have conducted studies indicating that political mistrust often boosts voter turnout, an outcome that seems unlikely if African Americans believe themselves to have no efficacy and assume that their votes will not count. Avery's article must be evaluated in the light of these findings: To some extent, African Americans believe their votes can bring about change in the system and increase the efficacy of black citizens. Instead, Avery's findings indicate that black voters who strongly identify with a particular racial group are more likely to be politically active in pursuing change within the system, and often pursue nontraditional forms of political protest and activism.

\section{Historical Discrimination}

From the Reconstruction Era forward, enormous opposition has existed to black suffrage. "Black codes" in the south prevented African Americans from voting, and although they were invalidated by the Fifteenth Amendment, voter intimidation continued. Jim Crow laws and the $\mathrm{Ku}$ Klux Klan significantly restricted voting rights of African Americans, and in the eyes of many blacks it seemed as though the federal government provided no response. Attempting to draw attention to the plight of African Americans, the Civil Rights movement advocated for change which eventually materialized in the form of the Voting Rights Act of 1965. Despite these advances, major problems still exist. Although legal segregation is now illegal, societal discrimination continues in many parts of society. There are significant disparities in wealth between white Americans and African Americans, and the Bureau of Justice reports that, although white Americans are more likely to use drugs, black people are arrested for drug possession more than three times as often. Today, the Black Lives Matter movement is drawing attention to violence against blacks from law enforcement officers. Racial discrimination past and present has been both ignored by and even supported by government, leaving many African Americans to be mistrustful and cynical of the government. Such attitudes have impacted the political behavior of blacks.

Recognizing this, many scholars begin with the origins of black frustration when discussing the voting patterns and political attitudes of African Americans. As Fullerton explains, "The domination of one-party southern politics by 'whites of the Black Belt' (Key 1949: 5) 
from the 1880 s to the 1960 s was based on the political and social exclusion of African Americans" (Fullerton 2013: 146). Historically, blacks have been barred from political participation and were forced to fight for their basic rights as American citizens. Their heritage has caused many African Americans to deal with a deep-seated mistrust of government and feelings of political inefficacy. However, the black response to these problems has been encouraging. Political mistrust leads to higher levels of political involvement, and African American efficacy is improving.

Dutter (2013: 60) explained how mistrust of the political system based on historical discrimination can lead to "abnormal politics." Essentially, when individuals believe that they have no power in the system, they must pursue a course of action outside the system to bring about change within. The author referenced events in the 50s and 60s when African Americans pursued peaceful actions such as demonstrations, marches, rallies, protests, and court cases in order to bring about political change. These events are examples of political cynicism leading to higher levels of political participation.

Tragically, abnormal politics can occasionally manifest itself through violence or in response to violence. African Americans have valid reasons to doubt both the system and their efficacy within the system. The important issue here is that, even if action was taken outside of the political system, the desired effect was for change to occur within the system, rather than for the system to be overthrown. However, other Americans should not be surprised at the lack of faith in the government held by many blacks in the US. Past failures may be remembered, even if subconsciously. For a full picture of political mistrust, one must examine the modern reasons that confirm the doubts related to old failures.

Mangum (2012: 3) explained the lack of political trust among African Americans by taking into account the effects of past discrimination. Specifically, he explored the impact of psychological involvement, policy satisfaction, and reference group on black trust of the government. First, the author defines political mistrust as, "A summary of both negative and positive evaluations of the government in Washington, D.C. It reflects the perception of how well the federal government is performing based upon expectations, which involves, to some degree, trust in public officials who serve in government, as well as both the system and process of government" (Mangum 3). African Americans tend to have far lower levels of political trust than other racial groups, and Mangum's models give several reasons for this discrepancy based on information from the 1996 National Black Election Study. First, the Psychological Involvement Model shows that levels of black mistrust are based on individual efficacy, group efficacy, political ideology, and party identification. Essentially, the level of influence citizens believe they have over the political process impacts their trust of government. Since blacks have experienced discrimination in the past, they question the amount of political efficacy they actually possess. However, as this article shows, black efficacy has improved substantially in the last few decades.

\section{Descriptive Representation}

Descriptive representation is the idea that political candidates should not only represent the political beliefs of their constituents but also share other politically significant characteristics such as race. When voters see a candidate with the same background, race, and gender, who has experienced the same struggles and discrimination, they feel included in the political process. The political alienation experienced by many minority groups is related to a lack of this descriptive representation. Although the election of an African American candidate does not guarantee the candidate's ideological solidarity with the entire black community, descriptive representation is experienced as a sort of personal victory for many African Americans, since it indicates that blacks are respected as equal members and participants in the political process.

Mangum (3) also examines the issue of descriptive representation using the Reference Group Model. When dealing with race, it appears that the number of black political leaders in power can impact political attitudes. This theory explains how the level of identification with a particular social group (in this instance, African Americans) affects an individual's trust in government. When black voters identify strongly with the African American community, they find the election of a black politician incredibly meaningful and a sign of progress. Unfortunately, descriptive representation such as this is not proportional to the African American population, a problem that explains the persistently high level of African American political mistrust.

Descriptive representation has a significant impact on African American political participation in addition 
to political mistrust. Griffin and Keane (2006: 999) found that, "...liberal African Americans are much more likely to vote when they are descriptively represented, while more conservative African Americans are less likely to vote" (Griffin 999). The authors suggested several reasons for this voting behavior. Descriptive representations may send a message that politics is not an "exclusionary" domain, and may also widen the knowledge of the groups being represented. Both of these factors are related to political mistrust. If politics is exclusionary, then it is only designed to further the interests of certain groups. This shows that the disadvantaged groups cannot trust the motives of those in power. If a group has more knowledge of the political process, it can more effectively utilize its power and affect change. When a political leader shares a similar background and, in a sense, the same "fate" which is influenced by race, a voter can assume that the politician is more likely to pursue goals that are beneficial to them. As a result, descriptive representation empowers minority groups. However, political ideology is more important than descriptive representation when it comes to voting, which is why liberal African Americans are more likely to vote when they are descriptively represented and conservative voters are not.

The idea that descriptive representation increases perceptions of political efficacy has been conveniently demonstrated in recent history. Merolla, Sellers, and Fowler (2013: 864) discussed the election of the United States' first African American president, Barack Obama, and its impact on political efficacy among African Americans. The study found that descriptive representation boosts political efficacy. However, there are a number of exceptions and nuances to this rule. Rather than increasing political efficacy for all groups, descriptive representation is tempered by other factors such as political party, strength of political affiliation, location, and ethnicity.

Fairdosi and Rogowski (2015: 337) elaborated on this by pointing out that party ideology is possibly more important for black voters than descriptive representation. Descriptive representation is only empowering when a candidate seems to hold beliefs and support policies which will further black interests. The authors cite "further evidence that black citizens' perceptions of black candidates' ideologies and character traits differed substantially based on the candidate's party" (Fairdosi 337). Interestingly, the authors went on to explain that a black candidate identifying with the Republican Party is far less likely to mobilize black voters than a Democratic candidate. Basing their arguments on previous studies, the authors postulate that the historical ties between the Democratic Party and African Americans make it incredibly difficult for black voters to justify voting for a Republican regardless of race. Fairdosi and Rogowski (346) observed that, "These ties may simply render it impossible for Republicans - black or otherwise - to move public opinion or mobilize voters among blacks, absent extraordinary circumstances." The authors concluded that descriptive representation is not enough to overcome fundamental political mistrust.

In all honesty, the effects of descriptive representation flow both ways. While a lack of descriptive representation increases political cynicism and eventually participation, the likelihood of voting increases when a black candidate is running for office. However, when combined, these two factors drastically increase voter turnout. A history of low descriptive representation will make the candidacy of an African American even more meaningful in mobilizing black voters.

\section{Political Efficacy}

The final piece of the puzzle is political efficacy. This is the degree to which a citizen feels he/she can influence political affairs. This is vital to understanding African American political behavior (an individual's belief about whether he/she can impact government). This usually determines whether people will participate in the political process. Niemi defines political efficacy as:

Political efficacy contains at least two separate components: (1) internal efficacy, referring to beliefs about one's own competence to understand, and to participate effectively in, politics, and (2) external efficacy, referring to beliefs about the responsiveness of governmental authorities and institutions to citizen demand. (Niemi 1991: 1407-1408)

In other words, internal efficacy is a measure of how much a person can impact the government, while external efficacy is a measure of how the government will respond. Although the issues are related, there is a clear distinction between them.

Political inefficacy tends to depress voter turnout. As Southwell (911) states, "Internal inefficacy reflects the individual's belief that he or she is unable to affect the course of political events and outcomes ... Such 
attitudes depress turnout because the individual is not convinced that the act of voting is likely to have much influence on political events or leaders." External inefficacy is an individual's perception of how responsive a government body is to the wishes and desires of society in general, rather than merely the individual. Many factors contribute to a sense of inefficacy among voters, but one way to raise perceptions of efficacy is membership in a voluntary organization. Swain and Mangum (2012: 189) argued that participation in some secular voluntary associations can increase the likelihood of political participation. The authors also suggested that, "Memberships in secular organizations are more influential facilitators of activism among Black Americans than the church ... Membership in secular organizations is related to high-intensity forms of political activity" (Swain and Mangum 189). Secular organizations give voters a sense of empowerment, making them feel as though they possess higher levels of political efficacy. As a result, members are more likely to be politically involved than non-members.

Williamson observed that African Americans actually experience greater efficacy than whites:

African Americans ... are more likely to attend public meetings than whites ... African Americans also reported higher levels of political efficacy than whites ... minorities [do not] necessarily suffer from lower levels of political efficacy than whites. (2015: 576)

Research like this is surprising, since high levels of political mistrust are typically associated with low levels of political efficacy. Although Williamson's results are limited to a study of public meetings, he also suggested that African Americans' attendance is based on a desire to reduce crime in the black community and deal with urgent issues. Sentiments such as these are likely to bring voters to the ballot box. This further shows that public meeting attendance typically correlates with voter turnout.

African American voters need to know their trip to the ballot box is worth the effort. Since blacks tend to be more politically active, researchers can conclude that African Americans experience relatively high levels of political efficacy. Shingles (1981: 76) showed the link between black consciousness and participation is mistrust combined with efficacy: The author also made the following statement:

Recent research has demonstrated that black Americans are far more politically active than whites of similar socioeconomic status. The difference has been related to black consciousness. Yet the reasons for this relationship have not been adequately explained ... this article theorizes that black consciousness contributes to political mistrust and a sense of internal political efficacy which in turn encourages policy-related participation. (Shingles 76)

As was mentioned earlier, "black consciousness" can be defined as possessing a strong sense of being a part of an African American community. With this consciousness comes both political mistrust, and, surprising as it may sound, internal political efficacy. When an African American becomes highly aware of their disadvantaged status in a society, they often shift the blame for their situation to the system. Shifting responsibility gives blacks a strong sense of efficacy and an equally strong degree of mistrust (Shingles 78). These two factors lead to higher rates of political participation.

\section{Political Mistrust Leads to Political Participation}

According to Southwell and Pirch (2003: 908), African Americans with higher levels of political mistrust are more likely to be politically active. For the purposes of this conversation, political participation refers to voting, fundraising, volunteering with a campaign, and donating to a campaign. Political cynicism and mistrust are related to an individual's belief that the government is not doing what is expected of it, what is right, and what benefits the population. The authors also suggested that mistrust will increase voter turnout because voters believe that political leaders are doing a poor job and must be replaced, and cynicism will only decrease political participation when it is found in conjunction with internal and external inefficacy (910).

There is a consensus among scholars that political cynicism leads to higher levels of political participation. Although inefficacy remains a problem for many voters, the results of widespread political mistrust among African Americans are largely positive. Guterbock states that, "Black 'distrustfuls' are the most active social and political participants among people with varying political orientations, regardless of race" (Guterbock 1983: 450). Strange though it may be, it seems that feelings of frustration, cynicism, and mistrust have led to statistically higher levels of involvement among African Americans. Blacks are angry about the state of the country, the lack of descriptive representation, and the discrimination they encounter each and every day on the streets 
of America. Since they do not trust current incumbents to implement policies that will make their lives better, African Americans use their votes to push for change.

A specific example of this behavior is the high level of black involvement in public meetings. According to Williamson, "Evidence presented here indicates that public meetings are not systematically fraught with a lack of minority representation. Instead, African-American citizens are more likely to attend a public meeting than white citizens" (586). An individual willing to attend a public meeting is going above and beyond his/ her "civic duty"; he/she is choosing to give up extra time and energy to make their voice heard. Contrary to claims that blacks are not politically involved, numbers like these demonstrate the level of passion and political involvement that exists within the African American community.

Historical oppression of an entire racial group of individuals has led to the current response of political activism and increasingly loud cries for recognition. Szymanski (2015) explains that: "African American person[s] continue to engage in collective responses to oppression" (171). In a culture increasingly torn by racial division and even violence, African Americans are choosing to band together and make their voices heard. While political involvement is only one of these avenues of expression, it is one of the most popular:

The most frequently endorsed [activism] behaviors among ... African American women and men were voting for political candidates that support African American issues ... and attending African American political ... activities and events. (Szymanski 171-172)

The current consensus among blacks is that change is needed and that political activism is one of the best ways to bring about that change.

While the majority of the evidence supports the idea that political mistrust leads to higher levels of political participation, scholars such as Hackey disagree with the conclusion that mistrust and efficacy increase voter turnout, arguing instead that, "While mistrust is significant, it is opposite ... predictions" (Hackey 1992: 86). According to Hackey, there should be a much stronger correlation between group consciousness and political orientation and participation. Hackey also argues that the frequency of contact with local officials can have a far greater effect on voter turnout than mistrust and efficacy. Although Hackey's arguments seem to be unbiased, the majority of scholars still agree with the argument that mistrust is common and it is influenced by descriptive representation, which affects voter turnout.

\section{Conclusion}

Based on the information presented, it can be concluded that numerous factors lead to higher levels of political mistrust among African Americans, and these levels of mistrust provoke both positive and negative responses. The study also shows that many scholars support the idea that high levels of racial group consciousness, awareness of past and present discrimination, and lack of descriptive representation lead to political cynicism among blacks. This political distrust often contributes to increased voter turnout and political participation. Heightened awareness of one's membership in a racial group increases an individual's sense of power via the group and mistrust of the government which abuses or, at the very least, fails to further the interests of the group. As a result, there is a greater likelihood that this individual will vote and attempt to change the injustice he/she perceives in the system.

African American mistrust is, in fact, often more related to injustice in the political system itself rather than merely mistrust in individual politicians. Racial group consciousness can also motivate an individual to seek governmental change through channels other than the ballot box, such as protest and court actions. In the past, avenues such as these have been a preferred means of political participation due to blatant discrimination. Discrimination is another factor influencing political mistrust. Increased descriptive representation lowers levels of mistrust. This was demonstrated in the last eight years during the election and presidency of Barack Obama. However, the effects of descriptive representation have been tempered by issues such as political party orientation. Finally, political mistrust and participation in voluntary associations has raised the levels of political participation among individuals, while political inefficacy will lower it.

The study also shows that there are major issues in the current political process and potential areas of growth that need to be addressed. Awareness of the problems within the political system motivates black voters to act for change. Increased descriptive representation is viewed as beneficial and as a sign of progress by many African Americans. Additionally, the study shows 
that there are major flaws in the political system when a significant voting demographic group feels discriminated against and underrepresented. Even if these negative feelings of mistrust lead to positive results, the fact remains that millions of members of a democracy feel voiceless. Change is therefore essential and urgent, in order to remind black voters that their lives, voices, and desires matter. Therefore, politicians should be resolute in pursuing policies that will benefit all members of their constituency. Discrimination must be recognized as real, pervasive, and a problem that needs to be addressed. Potential minority candidates should be encouraged to run for office.

More research is needed on the issue of political inefficacy, including the pervasiveness of internal and external efficacy. Further research of this magnitude will likely reveal more of the underlying problems African Americans perceive in the political system and hopefully reveal possible courses of action to let their voices be heard in the political process.

\section{Works Cited}

Austin, Sharon D. Wright, Richard T. Middleton, and Rachel Yon. "The Effect of Racial Group Consciousness on the Political Participation of African Americans and Black Ethnics in Miami-Dade County, Florida." Political Research Quarterly 65.3 (2012): 629-641. Political Science Complete. Web. 22 Jan. 2016.

Avery, James M. "Political Mistrust among African Americans and Support for the Political System." Political Research Quarterly 62.1 (2009): 132-145. Political Science Complete. Web. 22 Jan. 2016.

Dutter, Lee E. "Theoretical Perspectives on Ethnic Political Behaviors in the USA." Ethnopolitics 12.1 (2013): 50-71. Political Science Complete. Web. 22 Jan. 2016.

Fairdosi, Amir Shawn, and Jon C. Rogowski. "Candidate Race, Partisanship, and Political Participation: When Do Black Candidates Increase Black Turnout?" Political Research Quarterly 68.2 (2015): 337-349. Political Science Complete. Web. 28 Feb. 2016.

Fullerton, Andrew S., and Michael J. Stern. "Racial Differences in the Gender Gap in Political Participation in the American South, 1952-2004." Social Science History 37.2 (2013): 145-176. Political Science Complete. Web. 11 Apr. 2016.

Griffin, John D., and Michael Keane. "Descriptive Representation and the Composition of African American Turnout." American Journal of Political Science 50.4 (2006): 998-1012. Political Science Complete. Web. 22 Jan. 2016.
Guterbock, Thomas M., and Bruce London. "Race, Political Orientation, and Participation: An Empirical Test of Four Competing Theories." American Sociological Review 48.4 (1983): 439-453. SocINDEX with Full Text. Web. 11 Apr. 2016.

Hackey, Robert B. "Competing Explanations of Voter Turnout Among American Blacks." Social Science Quarterly (University of Texas Press) 73.1 (1992): 71-89. America: History and Life with Full Text. Web. 29 Feb. 2016.

Key, V. O., Jr. (1949) Southern Politics in State and Nation. Knoxville: University of Tennessee Press.

Mangum, Maurice. "Explaining African-American Political Trust: Examining Psychological Involvement, Policy Satisfaction, and Reference Group Effects." International Social Science Review 87.1/2 (2012): 3-18. Academic Search Complete. Web. 22 Jan. 2016.

Merolla, Jennifer L., Abbylin H. Sellers, and Derek J. Fowler. "Descriptive Representation, Political Efficacy, and African Americans in the 2008 Presidential Election." Political Psychology 34.6 (2013): 863-875. Business Source Complete. Web. 27 Feb. 2016.

Niemi, Richard G., Stephen C. Craig, and Franco Mattei. "Measuring Internal Political Efficacy in the $1988 \mathrm{Na}$ tional Election Study." American Political Science Review 85.4 (1991): 1407-1408. Business Source Premier. Web. 14 Apr. 2016.

Shingles, Richard D. "Black Consciousness and Political Participation: The Missing Link." American Political Science Review 75.1 (1981): 76-91. America: History and Life with Full Text. Web. 14 Apr. 2016.

Southwell, Priscilla L., and Kevin D. Pirch. "Political Cynicism and the Mobilization of Black Voters." Social Science Quarterly (Wiley-Blackwell) 84.4 (2003): 906917. SocINDEX with Full Text. Web. 29 Feb. 2016.

Swain, Randall D., and Maruice Mangum. "Truth Believers and True Believers: The Conditional Effects of Voluntary Associations on the Political Participation of Black Americans." American Review of Politics 33 (2012): 189210. Political Science Complete. Web. 28 Feb. 2016.

Szymanski, Dawn M., and Jioni A. Lewis. "Race-Related Stress and Racial Identity as Predictors of African American Activism." Journal of Black Psychology 41.2 (2015): 170-191. CINAHL Complete. Web. 11 Apr. 2016.

Taylor, Erica C. "Political Cynicism and the Black Vote." Harvard Journal of African American Public Policy 17 (2010): 3-10. Academic Search Complete. Web. 22 Jan. 2016.

Williamson, Anne R., and Michael J. Scicchitano. "Minority Representation and Political Efficacy in Public Meetings." Social Science Quarterly (Wiley-Blackwell) 96.2 (2015): 576-587. Business Source Premier. Web. 11 Apr. 2016. 